\title{
Bifidobacterium mongoliense genome seems particularly adapted to milk oligosaccharide digestion leading to production of antivirulent metabolites
}

Pauline Bondue ${ }^{1}$, Christian Milani ${ }^{2}$, Emilie Arnould ${ }^{1}$, Marco Ventura ${ }^{2}$, Georges Daube ${ }^{1}$, Gisèle LaPointe ${ }^{3}$ and Véronique Delcenserie ${ }^{1 *}(0)$

\begin{abstract}
Background: Human milk oligosaccharides (HMO) could promote the growth of bifidobacteria, improving young children's health. In addition, fermentation of carbohydrates by bifidobacteria can result in the production of metabolites presenting an antivirulent activity against intestinal pathogens. Bovine milk oligosaccharides (BMO), structurally similar to HMO, are found at high concentration in cow whey. This is particularly observed for 3'sialyllactose ( $\left.3^{\prime} \mathrm{SL}\right)$. This study focused on enzymes and transport systems involved in HMO/BMO metabolism contained in B. crudilactis and B. mongoliense genomes, two species from bovine milk origin. The ability of $B$. mongoliense to grow in media supplemented with whey or 3'SL was assessed. Next, the effects of cell-free spent media (CFSM) were tested against the virulence expression of Escherichia coli O157:H7 and Salmonella enterica serovar Typhimurium.

Results: Due to the presence of genes encoding $\beta$-galactosidases, $\beta$-hexosaminidases, $\alpha$-sialidases and $a$ fucosidases, $B$. mongoliense presents a genome more sophisticated and more adapted to the digestion of $\mathrm{BMO} /$ $\mathrm{HMO}$ than $B$. crudilactis (which contains only $\beta$-galactosidases). In addition, $\mathrm{HMO} / \mathrm{BMO}$ digestion involves genes encoding oligosaccharide transport systems found in B. mongoliense but not in B. crudilactis. B. mongoliense seemed able to grow on media supplemented with whey or $3^{\prime} S L$ as main source of carbon (8.3 \pm 1.0 and $6.7 \pm 0.3 \mathrm{log} \mathrm{cfu}$ / $\mathrm{mL}$, respectively). CFSM obtained from whey resulted in a significant under-expression of ler, fliC, luxS, stxl and qseA genes $(-2.2,-5.3,-2.4,-2.5$ and -4.8 , respectively; $P<0.05)$ of $E$. coli O157:H7. CFSM from 3'SL resulted in a significant up-regulation of luxS $(2.0 ; P<0.05)$ gene and a down-regulation of fliC $(-5.0 ; P<0.05)$ gene. CFSM obtained from whey resulted in significant up-regulations of sopD and hil genes ( 2.9 and 3.5, respectively; $P<0.05)$ of S. Typhimurium, while CFSM obtained from 3'SL fermentation down-regulated hil and sopD genes ( -2.7 and 4.2 , respectively; $P<0.05)$.

(Continued on next page)
\end{abstract}

\footnotetext{
* Correspondence: Veronique.Delcenserie@ulg.ac.be

'Department of Food Science, Fundamental and Applied Research for

Animal and Health, Faculty of Veterinary Medicine, University of Liège, Liège, Belgium

Full list of author information is available at the end of the article
}

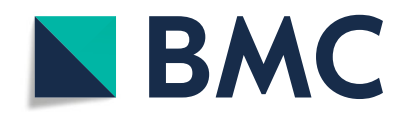

(c) The Author(s). 2020 Open Access This article is licensed under a Creative Commons Attribution 4.0 International License, which permits use, sharing, adaptation, distribution and reproduction in any medium or format, as long as you give appropriate credit to the original author(s) and the source, provide a link to the Creative Commons licence, and indicate if changes were made. The images or other third party material in this article are included in the article's Creative Commons licence, unless indicated otherwise in a credit line to the material. If material is not included in the article's Creative Commons licence and your intended use is not permitted by statutory regulation or exceeds the permitted use, you will need to obtain permission directly from the copyright holder. To view a copy of this licence, visit http://creativecommons.org/licenses/by/4.0/ The Creative Commons Public Domain Dedication waiver (http://creativecommons.org/publicdomain/zero/1.0/) applies to the data made available in this article, unless otherwise stated in a credit line to the data. 
(Continued from previous page)

Conclusion: From enzymes and transporters highlighted in the genome of $B$. mongoliense and its potential ability to metabolise 3'SL and whey, B. mongoliense seems well able to digest $\mathrm{HMO} / \mathrm{BMO}$. The exact nature of the metabolites contained in CFSM has to be identified still. These results suggest that BMO associated with $B$. mongoliense could be an interesting synbiotic formulation to maintain or restore intestinal health of young children.

Keywords: Bifidobacterium mongoliense, Bifidobacterium crudilactis, Whey, Bovine milk oligosaccharide, 3'sialyllactose, Antivirulent effect, Escherichia coli 0157:H7, Salmonella enterica serovar Typhimurium

\section{Background}

The carbohydrate sources present in food influence microbiota composition and have an impact on young children's health [1-3]. Simple and linear oligosaccharides, such as galacto-oligosaccharides (GOS) and fructo-oligosaccharides (FOS), are added to infant milk formula. They are bifidogenic but can be metabolised as well by other bacteria such as Bacteroides spp. or Clostridium spp., other bacteria found in the microbiota [4, 5]. In comparison, human milk is rich in complex sugars called human milk oligosaccharides (HMO). More than 500 structures have been identified and their concentration can reach up to $50 \mathrm{~g} / \mathrm{L}$ or more in the colostrum [6] and $15 \mathrm{~g} / \mathrm{L}$ in the mature milk [7]. The presence of $\alpha$ and $\beta$-bonds protects them against digestion by the host and by most bacteria. A little quantity of HMO is absorbed across the epithelial barrier to reach the systemic circulation and then be excreted in the urine [8]. In addition, free milk oligosaccharides are able to decrease pathogen colonisation of intestinal cells by altering cell surface glycosylation and to increase bifidobacteria adherence [9].

In children's faeces, the microbiota is dominated by Bifidobacterium longum (56.2\%) and Bifidobacterium bifidum (10.7\%) [10]. These two species, especially Bifidobacterium longum subsp. infantis, possess the enzymatic activity able to degrade these specific $\alpha$ - and $\beta$ bonds $[11,12]$. In addition, the bifidobacteria proportion in breastfed children's faeces can reach more than $90 \%$ [13]. In addition, bifidobacteria and lactic acid bacteria produce several metabolites inhibiting virulence gene expression of different pathogenic bacteria such as Escherichia coli O157:H7 [14, 15], Salmonella enterica serovar Typhimurium SA $941256[16,17]$ and Campylobacter jejuni [18].

Because they have a similar structure, bovine milk oligosaccharides (BMO) share common properties with HMO. More than 60 BMO have been identified [7] and a significant overlap between BMO and HMO has been demonstrated [19]. The BMO concentration in bovine milk is 20-fold lower than the HMO concentration in human milk [19]. In addition, the BMO degree of polymerisation is lower and fucosylated oligosaccharides are very poorly represented [19-22]. Like HMO, BMO present $\alpha$ - and $\beta$-bonds and are therefore protected against degradation by other bacteria [4]. With a concentration of $0.85 \mathrm{~g} / \mathrm{L}$ in colostrum, the 3 '-sialyllactose (3'SL: NeuAc $\alpha 2-3 \mathrm{Gal} \beta 1-4 \mathrm{Glc}$ ) is one of the most important BMO found in cow milk [23, 24].

The whey, a by-product issued from the dairy industry, is obtained after the casein precipitation [25]. Its composition, depending on the method of cheese manufacture, is rich in protein such as $\beta$-lactoglobulin and $\alpha$ lactalbumin, in lactose and in minerals [26]. The whey permeate (whey stripped of its large proteins after membrane filtration) contains the BMO found in the milk and may be considered as a potential source of prebiotics able to improve human health [25]. In addition, the high quantities of whey produced by the dairy industry could easily contribute to an oligosaccharides production at very large-scale, increasing its economic value [27]. The 3'SL is the most abundant oligosaccharide found in the whey permeate and its concentration in a whey issued from colostrum reached $94 \mathrm{~g} / \mathrm{L}$ [28]. The consumption of BMO issued from whey is safe and well-tolerated [29] and its supplementation with an appropriate probiotic had a bifidogenic effect [30].

The epithelial adhesion of $B$. longum subsp. infantis ATCC 15697 was improved up to 9.8-fold to HT-29 cells in presence of $3^{\prime} \mathrm{SL}$ and 6' sialyllactose (6'SL) [31] and up to 3.3-fold in the presence of immunoglobulin G enriched from bovine whey oligosaccharides [32]. Zeinhom et al. [15] highlighted the protective effect of Lactobacillus acidophilus La-5 grown in medium supplemented with whey against enterohaemorrhagic E. coli (EHEC) infection in mice. Recently, Cooper et al. [33] demonstrated that a synbiotic combination of $B$. animalis subsp. lactis CNCM I-3446 and whey permeate containing 3'SL had a strong bifidogenic effect on microbiota of children who were born to an HIV+ mother.

Before reaching the colon to digest oligosaccharides, bifidobacteria must survive the stomach acidity, bile salts and pancreatic enzymatic activity. Most bifidobacteria do not support the presence of oxygen, making their production at industrial scale more challenging. Two bifidobacterial strains isolated from raw cow milk cheese, Bifidobacterium mongoliense FR/49/f/2 and 
Bifidobacterium crudilactis $\mathrm{FR} / 62 / \mathrm{b} / 3$, are able to tolerate presence of oxygen and acidity $[34,35]$. In addition, their genome could encode enzymes degrading BMO [36]. Therefore, these two strains could be an interesting source of probiotics for formula supplementation [35].

The first aim of this study was to determine the enzymes and transport systems involved in BMO degradation using the complete genome of $B$. crudilactis LMG 23609 and $B$. mongoliense DSM 21395. The second aim of this work was to evaluate the potential growth of $B$. mongoliense FR/49/f/2 in culture media supplemented with whey or 3'SL and to assess the effects of filtered supernatants on virulence expression of E. coli O157:H7 and $S$. Typhimurium.

\section{Results}

\section{Enzymes and transporters involved in milk} oligosaccharides

From genome analysis of $B$. mongoliense DSM 21395, 57 genes encoding for glycoside hydrolases $(\mathrm{GH})$ were identified (Fig. 1a), among which 10 encode for GH family GH3, 12 for GH13 and 2 for GH33. Seventy and 19 genes encoding for glycoside transferases (GT) and carbohydrate-binding modules (CBM) were found, respectively (Fig. 1b and c). Six genes encoding for enzymes involved in $\mathrm{HMO}$ or BMO degradation were highlighted: one cytoplasmic $\beta$-hexosaminidase (GH20), one cytoplasmic $\alpha$-L-fucosidase (GH95), two cytoplasmic $\beta$-galactosidases (GH2 and GH42) and two extracellular $\alpha$-sialidases (GH33) (Fig. 2). In addition, 36 genes were predicted to be involved in sugars transport, among which 12 encode for HMO or BMO monosaccharides and oligosaccharides (Fig. 3b). Putative transporters belonging to the TCDB family 3.A.1.24, 3.A.1.25 and 3.A.1.2.20 provided glucose transport. Putative transporters 3.A.1.1.18, 3.A.1.2.22 and 3.A.1.1.48 assured transport of GlcNAc, oligosaccharides and lacto-N-biose or galacto-N-biose, respectively.

From genome analysis of B. crudilactis LMG 23609, 48 genes encoding for $\mathrm{GH}$ were identified (Fig. 1a), among which 3 encode for GH family GH3 and 12 for GH13. Sixty-eight and 19 genes encoding for GT and CBM were found, respectively (Fig. $1 \mathrm{~b}$ and c). Two genes encoding for cytoplasmic $\beta$-galactosidases $(\mathrm{GH} 2$ and GH42) were highlighted (Fig. 2). From the B. mongoliense DSM 21395 genome, 28 genes were predicted to be involved in sugars transport, among which eight encode for HMO or BMO monosaccharides and oligosaccharides (Fig. 3b). Putative transporters belonging to the TCDB family 2.A.1.68.1 and 2.A.7.5.5 provided glucose transport. Putative transporters 2.A.2.2.3 and 3.A.1.1.48 assured transport of galactose and lacto-N-biose or galacto-N-biose, respectively.

\section{Growth of $B$. mongoliense strain $\mathrm{FR} / 49 / \mathrm{f} / 2$}

The highest counts were observed on MRS2-G and MRS2-Wh media $(8.6 \pm 0.8 \log \mathrm{cfu} / \mathrm{mL}$ and $8.3 \pm 1.0 \mathrm{log}$ $\mathrm{cfu} / \mathrm{mL}$, respectively) and the lowest count on MRS2-3' SL medium $(6.7 \pm 0.3 \log \mathrm{cfu} / \mathrm{mL})$. No growth was observed on MRS2 medium $(6.0 \pm 0.1 \log \mathrm{cfu} / \mathrm{mL})$ (Table 1).

\section{Effect of CFSM on E. coli 0157:H7 virulence gene expression}

After an incubation of $4 \mathrm{~h}$, the CFSM had no negative impact on growth. The average OD of E. coli O157:H7 at $600 \mathrm{~nm}$ after $4 \mathrm{~h}$ exposure was around $0.91 \pm 0.14$, while it was initially at $0.05 \pm 0.03$. The CFSM obtained from MRS2-Wh medium induced statistically significant down-regulation of ler, fliC, luxS, stx 1 and qseA genes $(-2.2,-5.3,-2.4,-2.5$ and -4.8 , respectively; $P<0.05)$ (Fig. 4c). The CFSM from MRS2 medium induced a significant down-regulation of $f l i C, \operatorname{luxS}$ and $s t x 1$ genes $(-15.8,-9.5$ and -2.3 , respectively; $P<0.05)$ (Fig. 4a). A significant increase of ler gene expression was observed with this same medium, but too low to be biologically meaningful $(1.7 ; P<0.05)$. CFSM from MRS2-G medium tended to over-express the luxS gene (2.2) and two significant up-regulations of ler and stx 1 genes (5.3 and 2.5, respectively; $P<0.05$ ) were observed (Fig. $4 \mathrm{~b}$ ). A significant down-regulation of the $\mathrm{fliC}$ gene was noted with the CFSM from MRS2-3'SL medium $(-5.2 ; P<0.05)$ (Fig. 4d). A significant up-regulation was also observed with the luxS gene $(2.0 ; P<0.05)$, while the significant increase of the $s t x 1$ gene expression was considered too low to be biologically meaningful $(1.6 ; P<0.05)$. The details of the cycle threshold values corresponding to the effects of CFSM on E. coli O157:H7 genes expression are available in the Additional file 1: Table S1.

\section{Effect of CFSM on S. Typhimurium virulence gene expression}

After the $4 \mathrm{~h}$ incubation, the OD measurements showed no negative impact on growth. The average OD of $S$. Typhimurium at $600 \mathrm{~nm}$ and after $4 \mathrm{~h}$ of exposure was $0.90 \pm 0.04$, while it was initially at $0.05 \pm 0.02$. CFSM obtained from MRS2 medium induced a significant upregulation of the sopD gene $(2.8 ; P<0.05)$ (Fig. 5a) while the MRS2-Wh CFSM led to significant up-regulation of sopD and hil genes (2.9 and 3.4, respectively; $P<0.05$ ) (Fig. 5c).

Three significant up-regulations of hil, ssrB2 and sopD genes (11.6, 37.2, 47.5, respectively; $P<0.05$ ) were noted for the CFSM from MRS2-G medium (Fig. 5b). A trend for down-regulation of hil and sopD genes $(-2.7$ and 4.2 , respectively) was observed with CFSM obtained from MRS-3'SL medium (Fig. 5d). The details of the cycle threshold values corresponding to the effects of 


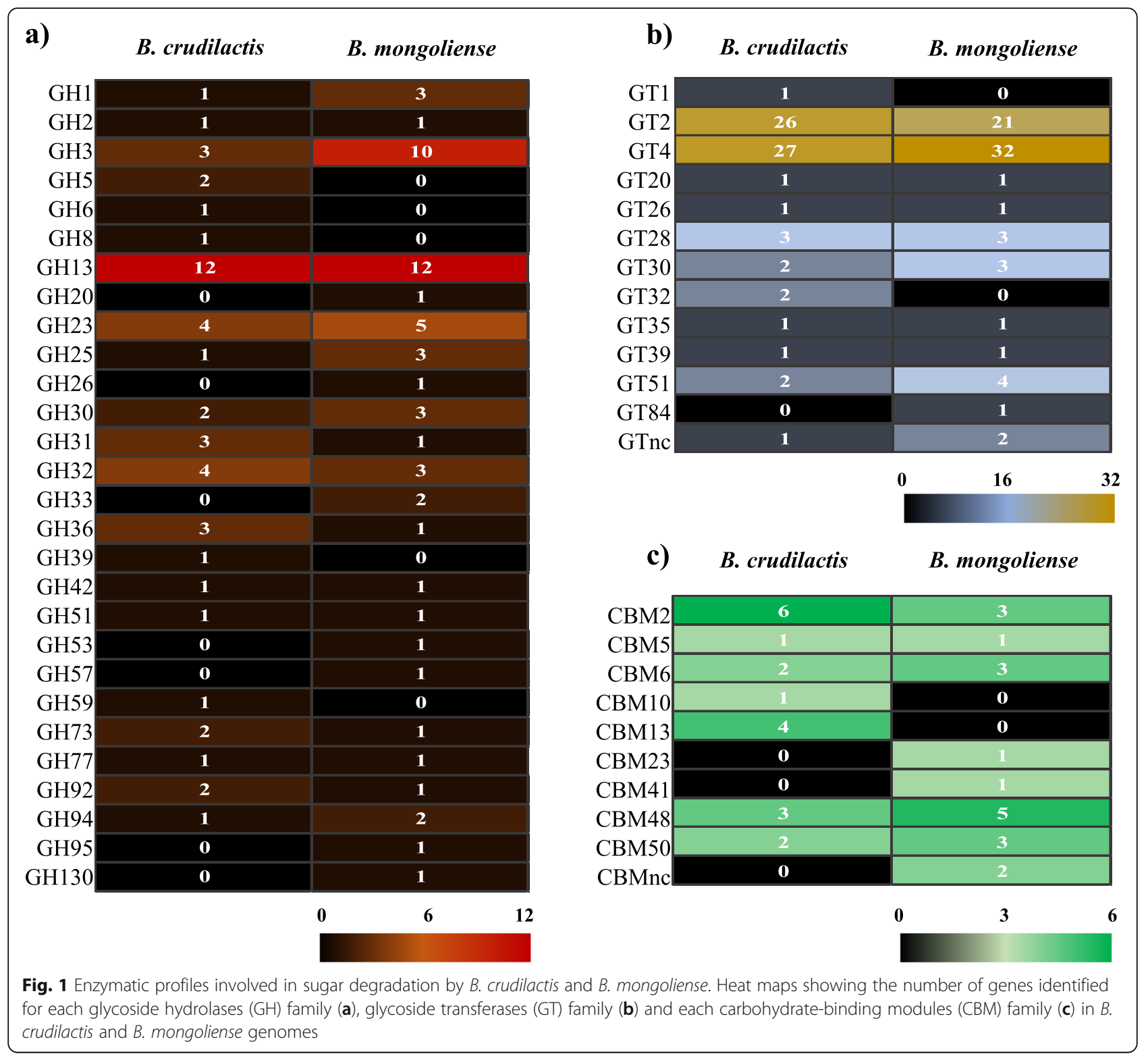

CFSM on $S$. Typhimurium genes expression are available in the Additional file 2: Table S2.

\section{Discussion}

As explained previously, $B$. mongoliense $\mathrm{FR} / 49 / \mathrm{f} / 2$ and $B$. crudilatis $\mathrm{FR} / 62 / \mathrm{b} / 3$ are both from bovine origin [35] but $B$. mongoliense seems to have an enzymatic arsenal more sophisticated to digest BMO compared to B. crudilactis. In the B. mongoliense DSM21395 genome, many genes encoded enzymes belonging to the GH families involved in complex carbohydrates degradation, such as GH2 ( $\beta$-galactosidase), GH3 (glucosidases), GH13 (amylases), GH20 ( $\beta$-hexosaminidases), GH33 ( $\alpha$-sialidases), GH42 ( $\beta$-galactosidases) and GH95 ( $\alpha$-L-fucosidases). Those genes were found in the $B$. crudilactis LMG
23609 genome too, with exception of those encoding for GH20 and GH95 (involved in HMO or BMO digestion) and GH33, which could be considered an advanced genetic adaptation to the intestinal environment due to its involvement in degradation of both $\mathrm{HMO} / \mathrm{BMO}$ and intestinal glycoconjugates such as mucin [37]. In addition, with its 14 potential genes involved in milk sugars transport, half of them being related to transfer of oligosaccharides, the transport system of $B$. mongoliense DSM21395 seems more efficient compared to B. crudilactis LMG 23609. Regarding B. crudilactis LMG 23609, eight potential genes are involved in milk sugar transport and most of them are involved in the transport of monosaccharides such as glucose and galactose. From the analysis of the TCDB families, $B$. mongoliense 


\begin{tabular}{|c|c|c|c|c|}
\hline & \multicolumn{2}{|c|}{ B. crudilactis } & \multicolumn{2}{|c|}{ B. mongoliense } \\
\hline & ORF & GH & ORF & GH \\
\hline Fucosidase & & & BMON 1216 & GH95 \\
\hline$\beta$-galactosidase & BCRU 0262 / BCRU 1422 & $\mathrm{GH} 42$ / GH2 & BMON $1218 / \mathrm{BMON} 1624$ & $\mathrm{GH} 2$ / GH42 \\
\hline \multicolumn{5}{|l|}{ LNB-phosphorylase } \\
\hline$\beta$-hexosaminidase & & & BMON 0456 & GH20 \\
\hline Sialidase & & & BMON 1674/BMON 1842 & GH33 / GH33 \\
\hline \multicolumn{5}{|c|}{ Number of predicted genes: } \\
\hline
\end{tabular}

Fig. 2 Digestion of milk oligosaccharides by B. crudilactis and B. mongoliense. The figure reports the presence/absence and CAZy classification of genes involved in milk oligosaccharides metabolism found in B. crudilactis and B. mongoliense genomes. Genes predicted to be intracellular are written in black while genes predicted to be extracellular are written in orange. ORF: open reading frame; GH: glycoside hydrolase

DSM21395 and B. crudilactis LMG 23609 could be able to transport LNB. However, LNB is a disaccharide associated with $\mathrm{HMO}$ rather than BMO [22]. Indeed, for most of the HMO, Gal and GlcNAc are linked to $\beta 1-3$ liaison (corresponding to LNB in HMO), contrarily to BMO, for which Gal and GlcNAc are linked to $\beta 1-4$ liaison (related to LacNac in BMO). In addition, the very high E-values observed with transporters belonging to the TCDB family 3.A.1.1.48 indicate a very low confidence index and could suggest that another disaccharide close to LNB, such as LacNac, could be internalised by B. mongoliense DSM21395 or B. crudilactis LMG 23609.

According to the schematic representation of the BMO metabolism available in the Additional file 3: Figure S3, B. mongoliense could be able to digest most of the oligosaccharides found in BMO, except the sialic acid, which is supposed to stay in the external environment. In the same way, B. mongoliense could be able to metabolise 3'SL (NeuAc 2 2-3Gal/1-4Glc) using an extracellular $\alpha$-sialidase. Then, the lactose (Gal $\beta 1-$ 4Glc) could be internalised using an $\mathrm{ABC}$ transporter and metabolised using a cytoplasmic $\beta$-galactosidase. According to this representation, the $\mathrm{BMO}$ or 3 'SL degradation by $B$. crudilactis seems impossible without a previous cross-feeding step involving other bifidobacteria.

B. mongoliense FR/49/f/2 showed good growth on media supplemented with either whey or glucose, whey contribution making no significant difference compared to glucose. In addition, whey is rich in lactose [38], a carbohydrate source easily consumed by bifidobacteria [39], and in several BMO (encompassing 3'SL) [25]. Finally, the important growth observed with the medium supplemented with whey is probably due to the high concentration in lactose, glucose and potentially BMO. Interestingly, the strain B. mongoliense FR/49/f/2 grew on medium containing 3'SL as the main carbohydrate source, in comparison to the absence of growth observed on medium without any carbohydrate source. According to B. mongoliense DSM21395 genome analysis, this growth could result from the expression of the enzymes cleaving BMO or 3'SL bonds, such as $\alpha$ sialidases, $\beta$-galactosidases and $\beta$-hexosaminidases. Genes involved in BMO degradation are also present in other bifidobacteria such as B. bifidum subsp. infantis and B. bifidum [36, 39, 40].

CFSM issued from lactic acid bacteria or bifidobacteria contained metabolites decreasing virulence genes expression of C. jejuni [18], E. coli O157:H7 [16] and $S$. Typhimurium [17]. In our study, CFSM obtained from medium supplemented with whey and fermented by $B$. mongoliense FR/49/f/2 was able to decrease E. coli O157: H7 ATCC 43890 virulence. All the 5 tested virulence genes were significantly under-expressed (ler, fliC, luxS, st 1 and qseA). Furthermore, with CFSM obtained from medium fermented without any glucose, three genes were significantly down-regulated $(f l i C, \operatorname{luxS}$ and stx 1$)$. In the study of Bondue et al. [41], CFSM obtained from medium supplemented with 3'SL and fermented by $B$. bifidum BBA1 and B. crudilactis $\mathrm{FR} / 62 / \mathrm{B} / 3$ presented a significant effect against E. coli O157:H7 ATCC 43890 virulence genes expression. Indeed, most of the virulence genes were down-regulated (ler, luxS, stxB2 and qseA), except the $f l i C$ gene, which tended to be up-regulated. These results are different from what is observed in this study with $B$. mongoliense (significant down-regulation of $\mathrm{fliC}$ gene and significant up-regulation of $\operatorname{luxS}$ and stx 1 genes). According to the genome of B. mongoliense, including many genes encoding enzymes from the $\mathrm{GH}$ family, metabolites produced in medium supplemented with 3'SL and fermented by B. mongoliense FR/49/f/2 could be different than those produced by $B$. crudilactis 


\begin{tabular}{|c|c|c|c|c|c|c|c|}
\hline \multicolumn{2}{|l|}{ a) } & \multicolumn{2}{|l|}{ B. crudilactis } & \multicolumn{2}{|l|}{ b) } & \multicolumn{2}{|c|}{ B. mongoliense } \\
\hline ORFs & TCDB family & TCDB Description & Sugar Transported & ORFs & TCDB family & TCDB Description & Sugar Transported \\
\hline BCRU_0171 & 3.A.1.1.45 & $\mathrm{ABC}$ transporter & Maltose & BMON_0262 & 3.A.1.1.27 & $\mathrm{ABC}$ transporter & Maltose/maltotriose/maltodextrin \\
\hline BCRU_0172 & 3.A.1.1.45 & $\mathrm{ABC}$ transporter & Maltose & BMON_0263 & 3.A.1.1.27 & $\mathrm{ABC}$ transporter & Maltose/maltotriose/maltodextrin \\
\hline BCRU 0200 & 2.A.8.1.1 & $\mathrm{H}+$ symporter & D-Gluconate & BMON_0264 & 3.A.1.1.27 & $\mathrm{ABC}$ transporter & Maltose/maltotriose/maltodextrin \\
\hline BCRU 0218 & 2.A.86.1.6 & Probable aldose transporter & Aldose & BMON_0403 & 3.A.1.1.24 & $\mathrm{ABC}$ transporter & Glucose/mannose \\
\hline RCPU 0360 & & & & BMON_0404 & 3.A.1.1.25 & $\mathrm{ABC}$ transporter & Glucose/mannose \\
\hline BCRU_OLOU & 3.A.1.1.48 & $\mathrm{ABC}$ transporter & Lacto-N-biose/galacto-N-biose & BMON_0429 & 3.A.1.2.20 & $\mathrm{ABC}$ transporter & Glucose /xylose \\
\hline BCRU_0261 & 3.A.1.1.48 & $\mathrm{ABC}$ transporter & Lacto-N-biose/galacto-N-biose & BMON_0430 & 3.A.1.2.20 & $\mathrm{ABC}$ transporter & Glucose /xylose \\
\hline BCRU_0264 & 3.A.1.1.48 & $\mathrm{ABC}$ transporter & Lacto-N-biose/galacto-N-biose & BMON_0441 & 3.A.1.1.23 & $\mathrm{ABC}$ transporter & Cellobiose/cellotriose \\
\hline BCRU_0970 & 2.A.1.7.17 & Putative fructose porter & Fructose & BMON_0442 & 3.A.1.1.23 & $\mathrm{ABC}$ transporter & Cellobiose/cellotriose \\
\hline BCRU_1142 & 2.A.1.68.1 & Glucose transporter & Glucose & BMON_0479 & 3.A.1.1.26 & $\mathrm{ABC}$ transporter & Maltose \\
\hline BCRU_1319 & 2.A.1.68.1 & Glucose transporter & Glucose & BMON_0480 & 3.A.1.1.22 & $\mathrm{ABC}$ transporter & Maltose \\
\hline BCRU 1423 & 2. A. 2.2 .3 & Galactose nermease & & BMON_0481 & 3.A.1.1.22 & $\mathrm{ABC}$ transporter & Maltose \\
\hline & & & Galactose & BMON_0688 & 3.A.1.2.22 & $\mathrm{ABC}$ transporter & Sugar \\
\hline BCRU_1459 & 2.A.1.68.1 & Glucose transporter & Glucose & BMON_0771 & 3.A.1.2.22 & $\mathrm{ABC}$ transporter & Sugar \\
\hline BCRU_1489 & 3.A.1.1.23 & $\mathrm{ABC}$ transporter & Cellobiose/cellotriose & BMON_0772 & 3.A.1.2.22 & $\mathrm{ABC}$ transporter & Sugar \\
\hline BCRU_1490 & 3.A.1.1.23 & $\mathrm{ABC}$ transporter & Cellobiose/cellotriose & BMON_0773 & 3.A.1.2.22 & $\mathrm{ABC}$ transporter & Sugar \\
\hline BCRU 1491 & 3.A.1.1.23 & $\mathrm{ABC}$ transporter & Cellobiose/cellotriose & BMON_0776 & 3.A.1.2.23 & $\mathrm{ABC}$ transporter & Sugar (fructose) \\
\hline BCRU_1504 & 3.A.1.1.45 & $\mathrm{ABC}$ transporter & Maltose & BMON_1054 & 2.A.1.7.5 & 2-Deoxy-D-ribose porter & 2-Deoxy-D-ribose \\
\hline BCRU_1507 & 3.A.1.1.45 & $\mathrm{ABC}$ transporter & Maltose & BMON_1236 & 3.A.1.1.26 & $\mathrm{ABC}$ transporter & Maltose \\
\hline BCRU_1508 & 3.A.1.1.45 & $\mathrm{ABC}$ transporter & Maltose & BMON_1237 & 3.A.1.1.52 & $\mathrm{ABC}$ transporter & $\begin{array}{l}\text { Sugar (sucrose, maltose, glucose, fructose, } \\
\text { esculin) }\end{array}$ \\
\hline BCRU_1509 & 3.A.1.1.45 & $\mathrm{ABC}$ transporter & Maltose & BMON_1238 & 3.A.1.1.45 & $\mathrm{ABC}$ transporter & Maltose \\
\hline BCRU_1526 & 3.A.1.1.28 & $\mathrm{ABC}$ transporter & Raffinose/stachyose & BMON_1409 & 3.A.1.1.45 & $\mathrm{ABC}$ transporter & Maltose \\
\hline BCRU_1527 & 3.A.1.1.28 & $\mathrm{ABC}$ transporter & Raffinose/stachyose & BMON_1421 & 3.A.1.1.28 & $\mathrm{ABC}$ transporter & Raffinose/stachyose \\
\hline BCRU 1528 & 3.A.1.1.28 & $\mathrm{ABC}$ transporter & Raffinose/stachyose & BMON_1422 & 3.A.1.1.29 & $\mathrm{ABC}$ transporter & Aldouronate \\
\hline BCRU 1538 & 2.A.7.5.5 & Glucose uptake porter & & BMON_1423 & 3.A.1.1.30 & $\mathrm{ABC}$ transporter & Glucose \\
\hline BCRU 1543 & 391123 & $\mathrm{BC}$ tronchorter & Glucose & BMON_1433 & 3.A.1.1.45 & $\mathrm{ABC}$ transporter & Maltose \\
\hline & & & Cellobiose/cellotriose & BMON_1446 & 3.A.1.1.45 & $\mathrm{ABC}$ transporter & Maltose \\
\hline BCRU_1600 & 3.A.1.5.6 & $\mathrm{ABC}$ transporter & $\beta$-glucoside/maltose & BMON_1447 & 3.A.1.1.46 & $\mathrm{ABC}$ transporter & Glucoside \\
\hline BCRU_1601 & 3.A.1.5.6 & $\mathrm{ABC}$ transporter & $\beta$-glucoside/maltose & BMON_1448 & 9.B.142.5.1 & Putative glycosyl transferase & Maltose \\
\hline BCRU_1602 & 3.A.1.5.6 & $\mathrm{ABC}$ transporter & $\beta$-glucoside/maltose & BMON_1623 & 3.A.1.1.48 & $\mathrm{ABC}$ transporter & Lacto-N-biose/galacto-N-biose \\
\hline BCRU_1603 & 3.A.1.5.8 & $\mathrm{ABC}$ transporter & $\beta$-glucoside/maltose & BMON_1649 & 3.A.1.1.48 & $\mathrm{ABC}$ transporter & Lacto-N-biose/galacto-N-biose \\
\hline$>5.50$ & & & & BMON_1650 & 3.A.1.1.48 & $\mathrm{ABC}$ transporter & Lacto-N-biose/galacto-N-biose \\
\hline$>$ E-50 & & & & BMON_1651 & 3.A.1.1.48 & $\mathrm{ABC}$ transporter & Lacto-N-biosegalacto-N-biose \\
\hline $\begin{array}{l}\text { E-50 }>x>\text { E-1 } \\
<\text { E-100 }\end{array}$ & & & & $\frac{\text { BMON_1652 }}{\text { BMON } 1757}$ & 3.A.1.2.1 & $\begin{array}{l}\mathrm{ABC} \text { transporter } \\
\mathrm{ABC} \text { transporter }\end{array}$ & $\begin{array}{l}\text { Ribose } \\
\text { Maltose, maltotriose, mannotetraose }\end{array}$ \\
\hline & & & & BMON 1763 & 3.A.1.1.18 & $\mathrm{ABC}$ transporter & N-Acetylglucosamine/ $\mathrm{N}, \mathrm{N}^{\prime}$-diacetyl chitobios \\
\hline
\end{tabular}

Fig. 3 Sugar transporters identified in B. crudilactis (a) and B. mongoliense (b) genomes. Genes involved in milk sugars transport are indicated in red while the others are indicated in black. An E-value close to zero is indicated in dark yellow while an E-value far from zero is indicated in pale yellow. ORF: open reading frame; TCDB: Transporter classification database; E: E-value

$\mathrm{FR} / 62 / \mathrm{B} / 3$ and $B$. bifidum BBA1. Also, the downregulation of the $f l i C$ gene while other virulence genes were up-regulated has already been demonstrated in other studies [42-44]. The media MRS2-G and MRS2Wh are rich in carbohydrates, and fermentation products such as lactate and acetate are synthesised. To prevent an inhibition of pathogenic bacteria growth due to media acidification, all CFSM were neutralised before testing them with $E$. coli or $S$. Typhimurium as described previously [16, 41].

Table 1 Counts of B. mongoliense after incubation in MRS2, MRS2-G, MRS2-Wh and MRS2-3'SL media

\begin{tabular}{ll}
\hline & $\begin{array}{l}\text { Final concentrations after } 48 \mathrm{~h} \text { incubation } \\
\text { (log cfu/ml) }\end{array}$ \\
\hline MRS2 & $6.0 \pm 0.1$ \\
MRS2-G & $8.6 \pm 0.8$ \\
MRS2-Wh & $8.3 \pm 0.8$ \\
MRS2-3'SL & $6.7 \pm 0.3$ \\
\hline
\end{tabular}

After contact with the CFSM, S. Typhimurium ATCC 14028 virulence gene expression was modulated, but not always in the same way as $E$. coli O157:H7 ATCC 43890. The CFSM from medium supplemented with glucose gave the same kind of regulation for both pathogens, and all the tested genes were over-expressed with S. Typhimurium (hil, ssrB2 and sopD). CFSM from media without any glucose or supplementation with whey down-regulated $E$. coli virulence genes, while these CFSMs induced mainly up-regulations of Salmonella virulence genes (hil and sopD). The only trend for down-regulation of Salmonella virulence genes was observed with CFSM supplemented with 3'SL (hil and sopD genes). The metabolites obtained from the fermentation of $3^{\prime} \mathrm{SL}$ by $B$. mongoliense could decrease pathogenicity of $S$. Typhimurium. This effect had already been observed with CFSM fermented by B. bifidum BBA1, where all the tested genes were under-expressed [41]. 


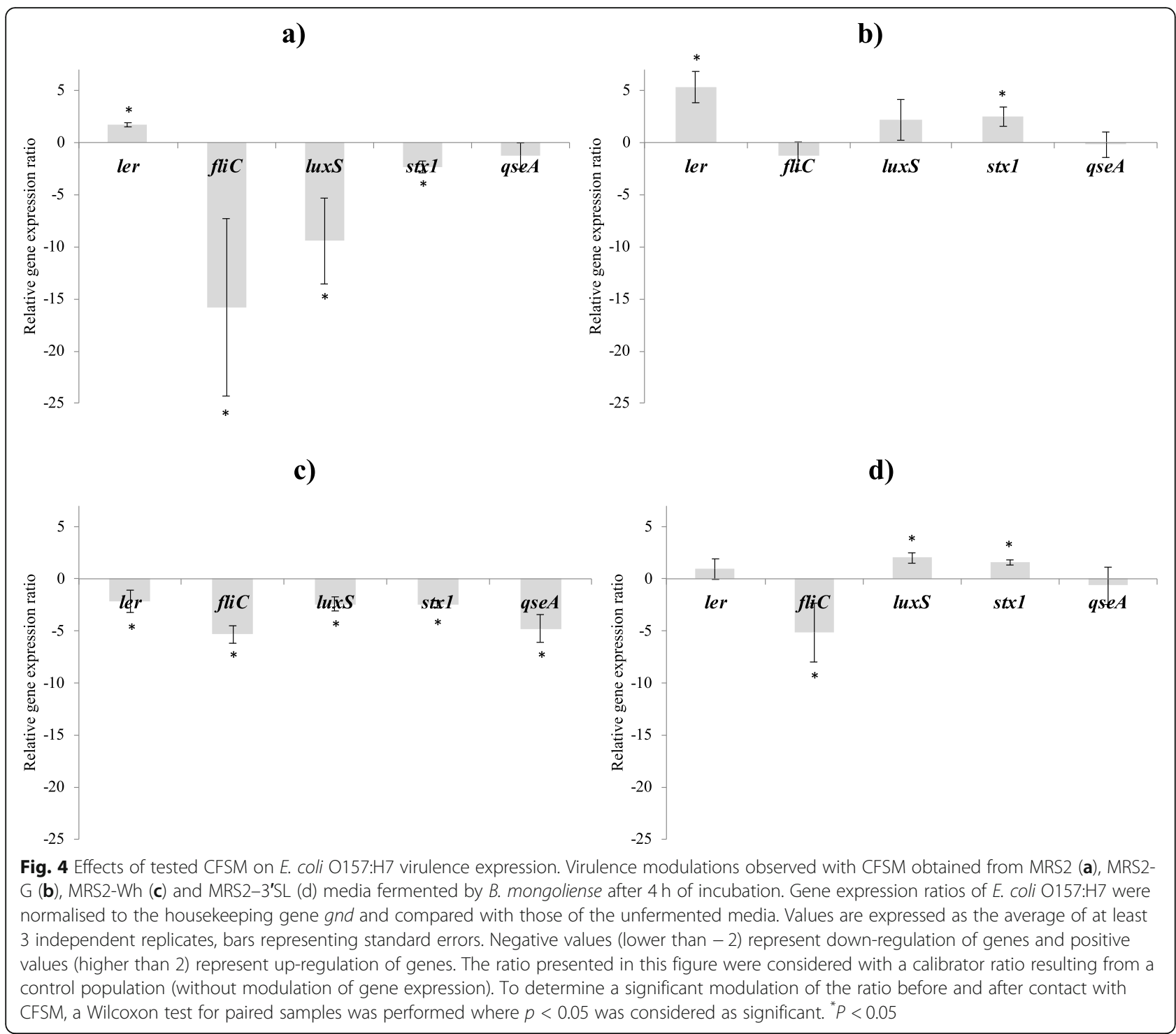

Little is known about the exact nature of these metabolites. These bioactive molecules could originate from the degradation of proteins such as nisin or subpeptins similar to JM4-A and JM4-B, produced by lactic bacteria and having an antimicrobial effect [45, 46]. The 3'SL or whey digestion by B. crudilactis FR/ $62 / \mathrm{b} / 3$ or $B$. mongoliense $\mathrm{FR} / 49 / \mathrm{f} / 2$ has an antivirulent effect on $E$. coli $\mathrm{O} 157: \mathrm{H} 7$ and $S$. Typhimurium [41] and these bioactive molecules could be related to some carbohydrate residues, if they are obtained from carbohydrate metabolism. $\beta$-galactosidase genes, necessary for 3'SL degradation, have been identified in the $B$. crudilactis LMG 23609 genome but do not seem sufficient to easily metabolise the BMO. The enzymatic machinery proposed for BMO degradation identified in the B. mongoliense DSM21395 genome is more sophisticated with the putative presence of $\beta$ galactosidases, but also with $\alpha$-sialidases and $\beta$ hexosaminidases. This highlights the putative capacity of $B$. mongoliense to metabolise the 3'SL and other complex BMO. The carbohydrate residues issuing from this degradation, such as sialic acid, glc, gal or GlcNac, could be involved in this antivirulent effect (Figure S3). The potential metabolites from 3'SL or whey degradation are probably different from those mentioned above and could explain why the 3'SL and whey fermentation by $B$. mongoliense FR/49/f/2 CFSM did not have the same antivirulence effect on $E$. coli O157:H7 compared to B. crudilactis FR/62/b/3 CFSM. Information is lacking about the exact nature of these molecules (peptides or glucidic residues), and a sizeexclusion chromatography in association with a mass 
a)

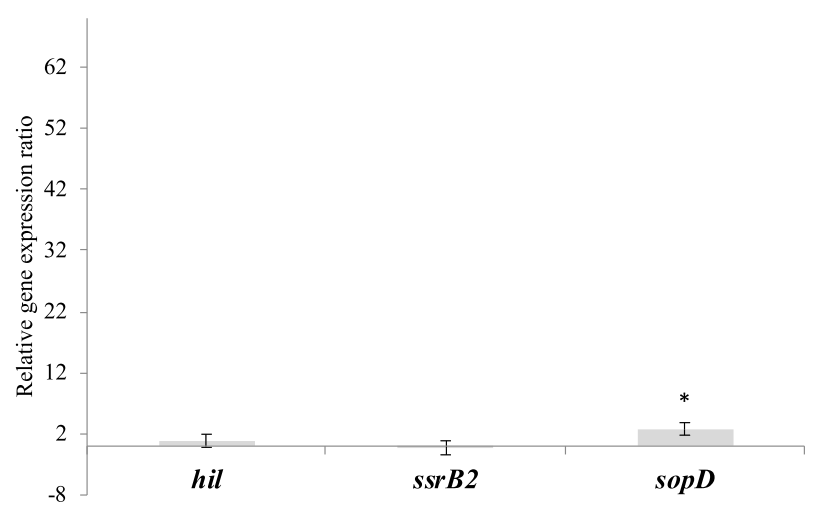

c)

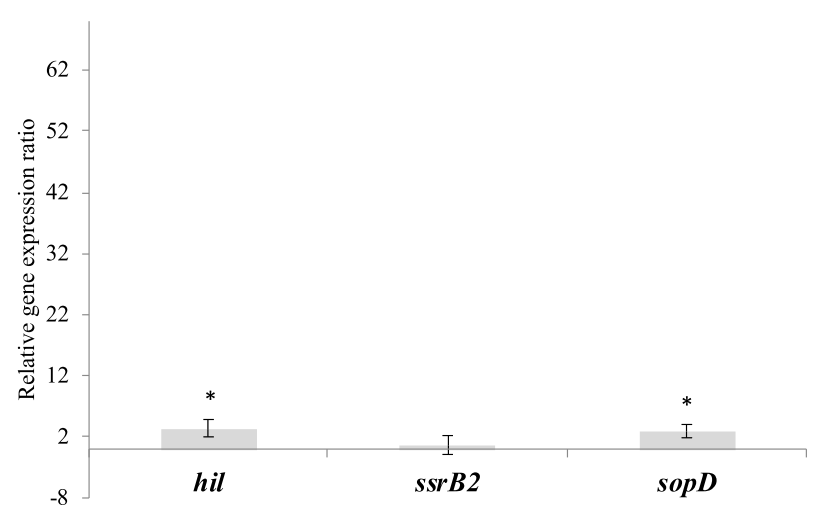

b)

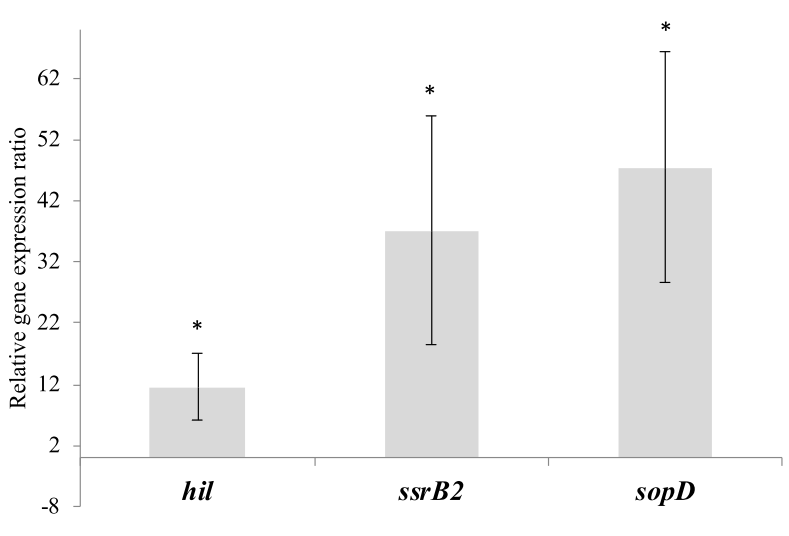

d)

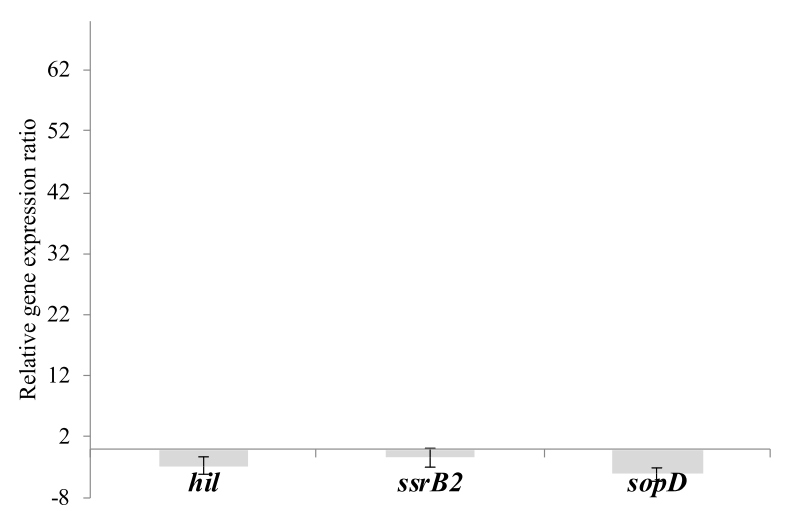

Fig. 5 Effects of tested CFSM on S. Typhimurium virulence expression. Virulence modulations observed with CFSM obtained from MRS2 (a), MRS2-G (b), MRS2-Wh (c) and MRS2-3'SL (d) media fermented by B. mongoliense after 4 h of incubation. Gene expression ratios of S.

Typhimurium were normalised to the housekeeping gene gmk and compared with those of the unfermented media. Values are expressed as the average of at least 3 independent replicates, bars representing standard errors. Negative values (lower than - 2) represent down-regulation of genes and positive values (higher than 2) represent up-regulation of genes. The ratio presented in this figure were considered with a calibrator ratio resulting from a control population (without modulation of gene expression). To determine a significant modulation of the ratio before and after contact with CFSM, a Wilcoxon test for paired samples was performed where $p<0.05$ was considered as significant. ${ }^{*} P<0.05$

spectrometry could contribute to further identifying them.

\section{Conclusions}

In conclusion, according to the genome analysis of $B$. mongoliense DSM21395 associated to the growth of $B$. mongoliense FR/49/f/2 on media supplemented with whey or 3'SL, B. mongoliense presents a genotype more adapted to the digestion of BMO compared to B. crudilactis. These two different kinds of metabolism observed for these two bifidobacteria species from bovine origin could have an impact on the nature of produced residual metabolites, which could differ in their influence on the virulence expression of pathogens. CFSM obtained from medium supplemented with whey and fermented by $B$. mongoliense FR/49/f/2 presented the most interesting effect by decreasing the virulence expression of the five tested genes of E. coli O157:H7 (ler, fliC, luxS, stx1 and qseA). For S. Typhimurium, the CFSM obtained after 3' SL fermentation presented the most interesting effect by decreasing 2 of the 3 tested genes (hil and sopD). According to this study, B. mongoliense FR/49/f/2 could be a potential probiotic, which associated to BMO, could maintain the young child's gastrointestinal health through a synbiotic effect.

\section{Methods}

\section{Genome analysis}

The genomes of the two reference strains, B. crudilactis LMG 23609 and B. mongoliense DSM 21395 are available on GenBank using accession number JHAL00000000 and JGZE00000000, respectively [35, 36, 
47]. The encoded genomes were submitted to homology search against the CAZy database (PMID: 24270786) using the MEGAnnotator software (REF PMID: 26936607). Transporters' specificity was predicted by means of the Transporter Classification DataBase (TCDB) (REF PMID: 26546518). Cellular localisation of putative $\mathrm{HMO} / \mathrm{BMO}$ degradation genes was defined based on the PSORTb v3.0 web server (REF PMID: 20472543).

\section{Bacterial strains and growth conditions}

B. mongoliense $\mathrm{FR} / 49 / \mathrm{f} / 2$ and B. crudilactis $\mathrm{FR} / 62 / \mathrm{b} / 3$ have been isolated from Saint-Marcellin, a raw cow milk cheese from the Vercors area (France). These strains as well as EHEC strain O157:H7 ATCC 43890 and S. enterica serovar Typhimurium strain ATCC 14028 were stored and grown following the experimental protocol described previously by Bondue et al. [41].

Four media with different carbohydrate sources were used: a medium without any glucose (MRS2), a reference medium with glucose (MRS2-G) [48], a medium with a mix of glucose and whey as a source of BMO (MRS2Wh), and a medium with 3 'SL (MRS2-3'SL) as the main source of carbohydrate (Table 2). The yeast extract, peptone of casein and glucose were provided by the Oxoid firm (Temse, Belgium). The tween 80 was provided by Sigma-Aldrich Laboratory (Diegem, Belgium) and the $\mathrm{K}_{2} \mathrm{HPO}_{4}, \mathrm{KH}_{2} \mathrm{PO} 4, \mathrm{NaCl}, \mathrm{MnSO}_{4} \cdot \mathrm{H}_{2} \mathrm{O}$, $\mathrm{MgSO}_{4} \cdot 7 \mathrm{H}_{2} \mathrm{O}, \mathrm{FeSO}_{4} \cdot 7 \mathrm{H}_{2} \mathrm{O}$ and cysteine by Merck Laboratory (Overijse, Belgium). Sweet whey $\left(12^{\circ} \mathrm{D}\right)$ was collected at the beginning of a curdling process in a Belgian cheese factory (Liège area, Belgium) and frozen at $-20^{\circ} \mathrm{C}$ before further use. Whey was then sterilised

Table 2 Composition of the modified MRS2 media adapted from Tanimomo et al. [48]

\begin{tabular}{|c|c|c|c|c|}
\hline & MRS2 & MRS2-G & MRS2-Wh & MRS2-3'SL \\
\hline Yeast extract (g/L) & 15.5 & 15.5 & 15.5 & 15.5 \\
\hline Peptone of casein $(\mathrm{g} / \mathrm{L})$ & 15.5 & 15.5 & 15.5 & 15.5 \\
\hline $\mathrm{K}_{2} \mathrm{HPO}_{4}(\mathrm{~g} / \mathrm{L})$ & 0.9 & 0.9 & 0.9 & 0.9 \\
\hline $\mathrm{KH}_{2} \mathrm{PO}_{4}(\mathrm{~g} / \mathrm{L})$ & 0.9 & 0.9 & 0.9 & 0.9 \\
\hline $\mathrm{NaCl}(\mathrm{g} / \mathrm{L})$ & 0.009 & 0.009 & 0.009 & 0.009 \\
\hline $\mathrm{MnSO}_{4} \mathrm{H}_{2} \mathrm{O}(\mathrm{g} / \mathrm{L})$ & 0.17 & 0.17 & 0.17 & 0.17 \\
\hline $\mathrm{MgSO}_{4} \cdot 7 \mathrm{H}_{2} \mathrm{O}(\mathrm{g} / \mathrm{L})$ & 0.007 & 0.007 & 0.007 & 0.007 \\
\hline $\mathrm{FeSO}_{4} \cdot 7 \mathrm{H}_{2} \mathrm{O}(\mathrm{g} / \mathrm{L})$ & 0.009 & 0.009 & 0.009 & 0.009 \\
\hline Tween $80(\mathrm{~mL} / \mathrm{L})$ & 0.9 & 0.9 & 0.9 & 0.9 \\
\hline Cysteine (g/L) & 0.4 & 0.4 & 0.4 & 0.4 \\
\hline Glucose (g/L) & - & 20 & 10 & - \\
\hline Whey (mL/L) & - & - & 500 & - \\
\hline 3'-sialyllactose (g/L) & - & - & - & 0.85 \\
\hline
\end{tabular}

using double filtration (Minisart ${ }^{\circ} 0.45 \mu \mathrm{m}$ and $0.2 \mu \mathrm{m}$, Sartorius, Vilvoorde, Belgium). The quantities of lactose and protein in MRS2-Wh medium were estimated to be around $25 \mathrm{~g} / \mathrm{L}$ and $4 \mathrm{~g} / \mathrm{L}$, respectively [38]. The 3 'SL, added to MRS2-3'SL, was provided by Carbosynth Laboratory (Berkshire, UK). The purity of the 3'SL was of minimum $98 \%$. The concentration of $0.85 \mathrm{~g} / \mathrm{L}$ was chosen to be close to natural concentrations found in colostrum [23]. The experiments to obtain the concentrated CFSM containing bioactive molecules issued from B. crudilactis $\mathrm{FR} / 62 / \mathrm{b} / 3$ metabolism, were elaborated by Bondue et al. [41]. B. mongoliense $\mathrm{FR} / 49 / \mathrm{f} / 2$ was grown in three independent experiments on De Man, Rogosa, and Sharpe (MRS) medium (Oxoid, Hampshire, UK) supplemented with cysteine- $\mathrm{HCl}(0.5 \mathrm{~g} / \mathrm{L})$ and mupirocin $(0.08 \mathrm{~g} / \mathrm{L})$ under anaerobic conditions at $37^{\circ} \mathrm{C}$ for $48 \mathrm{~h}$. A maximum of two successive cultures have been carried out in MRS broth to reach $8 \mathrm{log} / \mathrm{mL}$, prior to use. Next, the cultures were used to inoculate the four previously described media to reach $6 \mathrm{log} / \mathrm{mL}$ of bifidobacteria $(1 \% \mathrm{v} / \mathrm{v})$ (concentration was confirmed by plating several dilutions of bifidobacteria at day 0 post inoculation). Bacterial growth was determined using viable plate counts after $48 \mathrm{~h}$ incubation. CFSM were obtained after two centrifugation steps at $5000 \mathrm{rpm}$ (Eppendorf Centrifuge 5804, Hamburg, Germany) for $10 \mathrm{~min}$. Supernatants were then sterilised by double filtration (Minis$\operatorname{art}^{\ominus} 0.45 \mu \mathrm{m}$ and $0.2 \mu \mathrm{m}$, Sartorius, Vilvoorde, Belgium). Next, CFSM were freeze-dried (Virtis Benchtop 3.3EL, SPS Scientific, Suffolk, United Kingdom) and rehydrated with sterile distilled water to obtain a 10-fold concentration. The same treatment was applied to non-fermented culture media (controls). To prevent an inhibition of pathogenic bacteria growth due to media acidification, the $\mathrm{pH}$ of rehydrated CFSM was adjusted to 7 using $1 \mathrm{M}$ $\mathrm{NaOH}$.

Exposure of pathogenic strains to CFSM, gene expression analysis by RT-qPCR and statistical analysis

The applied method was fully described in the previous study of Bondue et al. [41]. E. coli O157:H7 ATCC 43890 and S. Typhimurium ATCC 14028 were incubated overnight at $37^{\circ} \mathrm{C}$ under agitation in $\mathrm{LB}$ and $\mathrm{BHI}$ broth, respectively. Volumes of $50 \mu \mathrm{L}$ of homogenised cultures and $450 \mu \mathrm{L}$ of each concentrated CFSM (fermented and unfermented) were then added to $4.5 \mathrm{~mL}$ of LB broth for $E$. coli and BHI broth for $S$. Typhimurium. Triplicate cultures were incubated at $37^{\circ} \mathrm{C}$ for $4 \mathrm{~h}$ [49] on a shaker at $150 \mathrm{rpm}$. E. coli O157:H7 and S. Typhimurium were grown in LB and BHI broth alone, respectively, as controls. Bacterial growth was determined by OD measurement at $600 \mathrm{~nm}$.

Cells were then collected by centrifugation at 5000 rpm for $10 \mathrm{~min}$ at room temperature (Eppendorf 
Centrifuge 5804, Hamburg, Germany) and pellets were suspended in Tris-EDTA buffer containing 1\% lysozyme (Roche, Mannheim, Germany). RNA was extracted using the RNeasy ${ }^{\circ}$ Mini Kit (Qiagen, Antwerp, Belgium) and DNA contamination was eliminated using the DNase I Recombinant RNase-free Kit (Roche Diagnostics GmbH, Mannheim, Germany). Samples were heated at $75^{\circ} \mathrm{C}$ for 10 min in order to inactivate the DNase. The concentration of RNA was normalised to $100 \mathrm{ng} / \mu \mathrm{L}$ for $E$. coli and to $50 \mathrm{ng} / \mu \mathrm{L}$ for $S$. Typhimurium. The RNA was then subjected to reverse transcription polymerase chain reaction (RT-PCR) using a high-capacity cDNA Reverse Transcription Kit (Applied Biosystems, Ghent, Belgium). Synthesis of cDNA was performed in a Mastercycler Gradient Thermocycler (Flexigene, Cambridge, United Kingdom) under the following conditions: $25^{\circ} \mathrm{C}$ for 10 min, $37^{\circ} \mathrm{C}$ for $120 \mathrm{~min}, 85^{\circ} \mathrm{C}$ for $5 \mathrm{~min}$ and a cooling step at $4{ }^{\circ} \mathrm{C}$. A no-RT control was made to confirm the absence of DNA contamination in each sample.

To highlight the effects of filtrated supernatants on virulence gene expressions of E. coli O157:H7 ATCC 43890, the expression of ler, fliC, stxl, luxS, and qseA genes was determined using qPCR with gnd as a reference housekeeping gene $[50,51]$. For $S$. Typhimurium ATCC 14028, the virulence expressions of hilA, ssrB2 and $\operatorname{sop} D$ genes were assessed using gmk as a reference housekeeping gene [52]. Quantitative PCR amplification was performed using the $\mathrm{GoTaq}^{\circ}$ qPCR Master Mix (Promega, Leiden, Netherlands) and using the Light Cycler 480 (Roche Diagnostics, Mannheim, Germany). The primers were synthesised by Eurogentec (Liège, Belgium) and had been designed and validated in previous studies [37]. The qPCR conditions for E. coli were: initial denaturation at $95^{\circ} \mathrm{C}$ for $3 \mathrm{~min}$; denaturation, annealing and elongation repeated 45 times: $95^{\circ} \mathrm{C}$ for $15 \mathrm{~s}, 58^{\circ} \mathrm{C}$ for $30 \mathrm{~s}$ and $72{ }^{\circ} \mathrm{C}$ for $45 \mathrm{~s}$; melting curve program of $60-95^{\circ} \mathrm{C}$ with a heating rate of $0.1{ }^{\circ} \mathrm{C} / \mathrm{s}$. The qPCR conditions for $S$. Typhimurium were: denaturation at $95^{\circ} \mathrm{C}$ for $10 \mathrm{~min}$; 40 cycles of amplification and quantification at $95^{\circ} \mathrm{C}$ for $30 \mathrm{~s}$, $56^{\circ} \mathrm{C}$ for $30 \mathrm{~s}$ and $72{ }^{\circ} \mathrm{C}$ for $30 \mathrm{~s}$; melting curve program of $60-95^{\circ} \mathrm{C}$ with a heating rate of $0.1^{\circ} \mathrm{C} / \mathrm{s}$. The experiments were replicated three independent times and special attention was given to the controls to exclude any potential effect observed from the non-fermented media as described previously $[41,49]$. The relative changes in gene expression were calculated using the Pfaffl formula [53]: ratio $=(\text { virulence gene Efficiency })^{\mathrm{Ct}}$ unfermented $-\mathrm{Ct}$ fermented $/$ (reference gene Efficiency) ${ }^{\mathrm{Ct}}$ unfermented - Ct fermented, with Efficiency $=10^{(-1 / \text { slope })}$. The ratio obtained was considered with a calibrator ratio resulting from a control population (without modulation of gene expression). To determine a significant modulation of the ratio before and after contact with CFSM, a Wilcoxon test for paired samples was performed where $p<0.05$ was considered as significant.

\section{Supplementary information}

Supplementary information accompanies this paper at https://doi.org/10. 1186/s12866-020-01804-9.

Additional file 1: Table S1. Cycle threshold values corresponding to the effects of tested CFSM on E. coli O157:H7 genes expression.

Additional file 2: Table S2. Cycle threshold values corresponding to the effects of tested CFSM on S. Typhimurium genes expression.

Additional file 3: Figure S3. Schematic representation of $\mathrm{BMO}$ and $3^{\prime}$ $\mathrm{SL}$ metabolism by B. mongoliense and B. crudilactis.

\section{Abbreviations}

3'SL: 3'-sialyllactose; AE: Attaching and effacing; BHI: Brain heart infusion; BMO: Bovine milk oligosaccharide; CBM: Carbohydrate-binding module; CFSM: Cell-free spent medium; E: E-value; EHEC: Enterohaemorrhagic Escherichia coli; FOS: Fructo-oligosaccharide; fuc: Fucose; gal: Galactose; GH: Glycoside hydrolase; GT: Glycoside transferase; glc: Glucose; GlcNAc: Nacetylglucosamine; GOS: Galacto-oligosaccharide; HIV: Human

immunodeficiency virus; HMO: Human milk oligosaccharide; LacNac: Nacetyllactosamine; LB: Luria Bertani; LNB: Lacto-N-biose; LNnt: Lacto-Nneotetraose; LNT: Lacto-N-tetraose; MRS: De Man, Rogosa and Sharpe; NeuAc: N-acetylneuraminic acid or sialic acid; NeuGc: N-glycolylneuraminic acid; OD: Optical density; ORF: Open reading frame; TCDB: Transporter classification database; T3SS: Type III system secretion

\section{Acknowledgments}

The author wishes to acknowledge François Brose for his valuable help on this project.

\section{Authors' contributions}

PB and EA did the experiments. PB interpreted the results and wrote the manuscript. CM, MV, GL and GD were involved in the design of the study and provided help for interpretation of the results. VD participated in the design of the study, interpretation of the results and writing of the manuscript. All the authors have read and approved the manuscript.

\section{Funding}

This study was funded by the «Fond Opportunité » from ULiège. The funding had no influence in the design of the study, the collection, the analysis, the interpretation of data and the writing of the manuscript.

Availability of data and materials

All data are available from the corresponding author on reasonable request.

Ethics approval and consent to participate

Not applicable.

Consent for publication

Not applicable.

\section{Competing interests}

The authors declare that the research was conducted in the absence of any commercial or financial relationships that could be construed as a potential conflict of interest. Christian Milani and Marco Ventura, members of the editorial board, and all the authors have no competing interests.

\section{Author details}

${ }^{1}$ Department of Food Science, Fundamental and Applied Research for Animal and Health, Faculty of Veterinary Medicine, University of Liège, Liège, Belgium. 'Laboratory of Probiogenomics, Department of Chemistry, Life Sciences and Environmental Sustainability, University of Parma, Parma, Italy. ${ }^{3}$ Canadian Research Institute for Food Safety, University of Guelph, Guelph, Canada. 


\section{Received: 30 April 2019 Accepted: 26 April 2020}

\section{Published online: 07 May 2020}

\section{References}

1. Arrieta MC, Stiemsma LT, Amenyogbe N, Brown EM, Finlay B. The intestinal microbiome in early life: health and disease. Front Immunol. 2014;5:427.

2. Smilowitz JT, Lebrilla CB, Mills DA, German JB, Freeman SL. Breast milk oligosaccharides: structure-function relationships in the neonate. Annu Rev Nutr. 2014;34:1-27.

3. Scott KP, Antoine J, Midtvedt T, Van Hemert S. Manipulating the gut microbiota to maintain health and treat disease. Microb Ecol Health Dis. 2015;1:1-10

4. Chichlowski M, German JB, Lebrilla CB, Mills DA. The influence of milk oligosaccharides on microbiota of infants: opportunities for formulas. Annu Rev Food Sci Technol. 2011:2:331-51.

5. Scholtens PA, Goosens DA, Staiano A. Stool characteristics of infants receiving short-chain galacto-oligosaccharides and long-chain fructooligosaccharides: a review. World J Gastroenterol. 2014;20:13446-52.

6. Lane JA, O'Callaghan J, Carrington SD, Hickey RM. Transcriptional response of HT-29 intestinal epithelial cells to human and bovine milk oligosaccharides. Br J Nutr. 2013;110:2127-37.

7. Pacheco AR, Barile D, Underwood MA, Mills DA. The impact of the milk glycobiome on the neonate gut microbiota. Annu Rev Anim Biosci. 2015;3: 419-45.

8. Triantis $V$, Bode L, van Nerveen RJJ. Immunological effects of human milk oligosaccharides. Front Pediatr. 2018:6:190

9. Ross SA, Lane JA, Marotta M, Kavanaugh D, Ryan JT, Joshi L, Hickey RM. The role of oligosaccharides in host-microbial interactions for human health. J Clin Gastroenterol. 2016:50:S131-2.

10. Turroni F, Peano C, Pass DA, Foroni E, Severgnini M, Claesson MJ, Kerr C, Hourihane J, Murray D, Fuligni F, Gueimonde M, Margolles A, De Bellis G, OToole PW, van Sinderen D, Marchesi JR, Ventura M. Diversity of bifidobacteria within the infant gut microbiota. PLoS One. 2012;7:e36957.

11. Garrido D, Dallas DC, Mills DA. Consumption of human milk glycoconjugates by infant-associated bifidobacteria: mechanisms and implications. Microbiology. 2013;159:649-64.

12. Di Gioia D, Aloisio I, Mazzola G, Biavati B. Bifidobacteria: their impact on gut microbiota composition and their applications as probiotics in infants. Appl Microbiol Biotechnol. 2014;98:563-77.

13. Hidalgo-Cantabrana C, Delgado S, Ruiz L, Ruas-Madiedo P, Sanchez B, Margolles A. Bifidobacteria and their health-promoting effects. Microbiol Spectrum. 2017:5:3.

14. Medellin-Pena MJ, Griffiths MW. Effect of molecules secreted by Lactobacillus acidophilus strain La-5 on Escherichia coli O157:H7 colonization. Appl Environ Microbiol. 2009;75:1165-72.

15. Zeinhom M, Tellez AM, Delcenserie V, El-Kholy AM, El-Shinawy SH, Griffiths MW. Yoghurt containing bioactive molecules produced by Lactobacillus acidophilus La-5 exerts a protective effect against enterohemorrhagic Escherichia coli (EHEC) in mice. J Food Prot. 2012;10:1796-805.

16. Medellin-Pena MJ, Wang H, Johnson R, Anand S, Griffiths MW. Probiotics affect virulence-related gene expression in Escherichia coli 0157:H7. Appl Environ Microbiol. 2007;73:4259-67.

17. Bayoumi MA, Griffiths MW. In vitro inhibition of expression of virulence genes responsible for colonization and systemic spread of enteric pathogens using Bifidobacterium bifidum secreted molecules. Int J Food Microbiol. 2012;156:255-63

18. Mundi A, Delcenserie V, Amiri-Jami M, Moorhead S, Griffiths MW. Cell-free preparations of Lactobacillus acidophilus strain La-5 and Bifidobacterium longum strain NCC2705 affect virulence gene expression in Campylobacter jejuni. J Food Prot. 2013;76:1740-6.

19. Barile D, Tao N, Lebrilla CB, Coisson JD, Arlorio M, German JB. Permeate from cheese whey ultrafiltration is a source of milk oligosaccharides. Int Dairy J. 2009;19:524-30.

20. Tao N, DePeters EJ, German JB, Grimm R, Lebrilla CB. Variations in bovine milk oligosaccharides during early and middle lactation stages analyzed by high-performance liquid chromatography-chip/mass spectrometry. J Dairy Sci. 2009;92:2991-3001

21. Kelly V, Davis S, Berry S, Melis J, Spelman R, Snell R, Lehnert K, Palmer D. Rapid, quantitative analysis of $3^{\prime}$ - and 6'-sialyllactose in milk by flowinjection analysis-mass spectrometry: screening of milks for naturally elevated sialyllactose concentration. J Dairy Sci. 2013;96:7684-91.
22. Tao N, DePeters EJ, Freeman S, German JB, Grimm R, Lebrilla CB. Bovine milk glycome. J Dairy Sci. 2008;91:3768-78.

23. Nakamura T, Kawase H, Kimura K, Watanabe Y, Ohtani M, Arai I, Urashima T. Concentrations of sialyloligosaccharides in bovine colostrum and milk during the prepartum and early lactation. J Dairy Sci. 2003;86:1315-20.

24. Urashima T, Taufik E, Fukuda K, Asakuma S. Recent advances in studies on milk oligosaccharides of cows and other domestic farm animals. Biosci Biotechnol Biochem. 2013;77:455-66.

25. Dallas DC, Weinborn V, de Moura BJMLN, Wang M, Parker EA, Guerrero A, Hettinga KA, Lebrilla CB, German JB, Barile D. Comprehensive peptidomic and glycomic evaluation reveals that sweet whey permeate from colostrum is a source of milk protein-derived peptides and oligosaccharides. Food Res Int. 2014:63:203-9.

26. Walzem RL, Dillard CJ, German JB. Whey components: millenia of evolution create functionalities for mammalian nutrition: what we know and what we may be overlooking. Crit Rev Food Sci Nutr. 2002;42:353-75.

27. Lee $H$, de MeloSilva V, Liu Y, Barile D. Short communication: quantification of carbohydrates in whey permeate products using high-performance anion-exchange chromatography with pulsed amperometric detection. J Dairy Sci. 2015;98:7644-9.

28. Lee H, Cuthbertson DJ, Otter DE, Barile D. Rapid screening of bovine milk oligosaccharides in a whey permeate product and domestic animal milks by accurate mass database and tandem mass spectral library. J Agric Food Chem. 2016;64:6364-74

29. Smilowitz JT, Lemay DG, Kalanetra KM, Chin EL, Zivkovic AM, Breck MA, German JB, Mills DA, Slupsky C, Barile D. Tolerability and safety of the intake of bovine milk oligosaccharides extracted from cheese whey in healthy human adult. J Nutr Sci. 2017:6:1-11.

30. Meli F, Puccio G, Cajozzo C, Ricottone GL, Pecquet S, Sprenger N, Steenhout $P$. Growth and safety evaluation of infant formulae containing oligosaccharides dervived from bovine milk: a randomized, double-blind, noninferiority trial. BMC Pediatr. 2014;14:306.

31. Kavanaugh DW, O'Callaghan J, Butto LF, Slattery H, Lane J, Clyne M, Kane M, Joshi L, Hickey RM. Exposure of Bifidobacterium longum subsp infantis to milk oligosaccharides increases adhesion to epithelial cells and induces a substantial transcriptional response. PLOS ONE. 2013:8:e67224

32. Quinn EM, Slattery H, Thompson AP, Kilcoyne M, Joshi L, Hickey RM. Mining milk for factors which increase the adherence of Bifidobacterium longum subsp infantis to intestinal cells. Foods. 2018;7:196

33. Cooper P, Bolton KD, Velaphi S, de Groot N, Emady-Azar S, Pecquet S, Steenhout $P$. Early benefits of a starter formula enriched in prebiotics on the gut microbiota of healthy infants born to HIV+ mothers: a randomized double-blind controlled trial. Clin Med Insights Pediatr. 2016;10:119-30.

34. Daube G, Delcenserie V, Gavini F. Probiotic Bifidobacterial species. PCT/ EP2006/061247, US 20080274085, WO 2006/122850, 31-03-2006, USA, Europe. 2006

35. Delcenserie V, Taminiau B, Gavini F, de Schaetzen MA, Cleenwerck I, Theves M, Mahieu M, Daube G. Detection and characterisation of Bifidobacterium crudilactis and $B$ mongoliense able to grow during the manufacturing process of French raw milk cheeses. BMC Microbiol. 2013;13:239.

36. Milani C, Lugli GA, Duranti S, Turroni F, Bottacini F, Mangifesta M, Sanchez B, Viappiani A, Mancabelli L, Taminiau B, Delcenserie V, Barrangou R, Margolles A, van Sinderen D, Ventura M. Genomic encyclopedia of type strains of the genus Bifidobacterium. Appl Environ Microbiol. 2014;80:6290-302.

37. Milani C, Turroni F, Duranti S, Lugli GA, Mancabelli L, Ferrario C, van Sinderen D, Ventura M. Genomics of the genus Bifidobacterium reveals species-specific adaptation to the glycan-rich gut environment. Appl Environ Microbiol. 2016:82:980-91.

38. Food and Agriculture Organization (FAO). Le lait et les produits laitiers dans la nutrition humaine. http://www.fao.org/docrep/t4280f/t4280f0h.htm (1998). Accessed 26 March 2018.

39. Delcenserie V, Gavini F, Beerens H, Tresse O, Franssen C, Daube G. Description of a new species, Bifidobacterium crudilactis sp. nov. isolated from raw milk and raw milk cheeses. Syst Appl Microbiol. 2007; 30:381-9.

40. Bondue P, Delcenserie V. Genome of bifidobacteria and carbohydrate metabolism. Korean J Food Sci Anim Resour. 2015;35:1-9.

41. Bondue $P$, Crèvecoeur $S$, Brose $F$, Daube G, Seghaye MC, Griffiths MW LaPointe G, Delcenserie V. Cell-free spent media obtained from Bifidobacterium bifidum and Bifidobacterium crudilactis grown in media supplemented with 3 '-sialyllactose modulate virulence gene expression in 
Escherichia coli O157:H7 and Salmonella typhimurium. Front Microbiol. 2016; 7:1460.

42. Carey CM, Kostrzynska M, Thompson S. Escherichia coli O157:H7 stress and virulence gene expression on romaine lettuce using comparative real-time PCR. J Microbiol Methods. 2009;2:235-42.

43. Mei GY, Tang J, Carey C, Bach S, Kostrzynska M. The effect of oxidative stress on gene expression of Shiga toxin-producing Escherichia coli (STEC) 0157: H7 and non-0157 serotypes. Int J Food Microbiol. 2015;215:7-15.

44. Singh $R$, Jiang $X$. Expression of stress and virulence genes in Escherichia coli O157:H7 heat shocked in fresh dairy compost. J Food Prot. 2015;78:31-41.

45. Sumi CD, Yang BW, Yeo IC, Hahm YT. Antimicrobial peptides of the genus Bacillus: a new era for antibiotics. Can J Microbiol. 2015;61:93-103.

46. Ebbensgaard A, Mordhorst H, Overgaard MT, Nielsen CG, Aarestrup FM, Hansen EB. Comparative evaluation of antimicrobial activity of different antimicrobial peptides against a range of pathogenic bacteria. PLoS One. 2015;10:e0144611.

47. Lugli GA, Milani C, Turroni F, Duranti S, Ferrario C, Viappiani A, Mancabelli L, Mangifesta M, Taminiau B, Delcenserie V, van Sinderen D, Ventura M. Investigation of the evolutionary development of the genus Bifidobacterium by comparative genomics. Appl Environ Microbiol. 2014;80:6383-94.

48. Tanimomo J, Delcenserie V, Taminiau B, Daube G, Saint-Hubert C, Durieux A. Growth and freeze-drying optimization of Bifidobacterium crudilactis. Food Nutr Sci. 2016;7:616-26.

49. Delcenserie V, Lapointe G, Charaslertrangsi T, Rabalski A, Griffiths MW. Glucose decreases virulence gene expression of Escherichia coli O157:H7. J Food Prot. 2012:75:748-52.

50. Tellez A, Corredig M, Guri A, Zanabria R, Griffiths MW, Delcenserie V. Bovine milk fat globule membrane affects virulence expression in Escherichia coli O157:H7. J Dairy Sci. 2012;95:6313-9.

51. Mith H, Clinquart A, Zhiri A, Daube G, Delcenserie V. The impact of oregano (Origanum heracleoticum) essential oil and carvacrol on virulence gene transcription by Escherichia coli 0157:H7. FEMS Microbiol Lett. 2014;362:1-7.

52. Guri A, Paligot M, Crèvecoeur S, Piedboeuf B, Claes J, Daube G, Corredig M, Griffiths MW, Delcenserie V. In vitro screening of mare's milk antimicrobial effect and antiproliferative activity. FEMS Microbiol Lett. 2016;363:1-7.

53. Pfaffl MW. A new mathematical model for relative quantification in real-time RT-PCR. Nucleic Acids Res. 2001;29:2002-7.

\section{Publisher's Note}

Springer Nature remains neutral with regard to jurisdictional claims in published maps and institutional affiliations.

Ready to submit your research? Choose BMC and benefit from:

- fast, convenient online submission

- thorough peer review by experienced researchers in your field

- rapid publication on acceptance

- support for research data, including large and complex data types

- gold Open Access which fosters wider collaboration and increased citations

- maximum visibility for your research: over $100 \mathrm{M}$ website views per year

At $\mathrm{BMC}$, research is always in progress.

Learn more biomedcentral.com/submissions 